\title{
Translation problems and translation strategies involved in human and machine translation: Empirical studies
}

\author{
Birte Prahl \\ Susanne Petzolt \\ Universität Hildesheim
}


Juni 1997

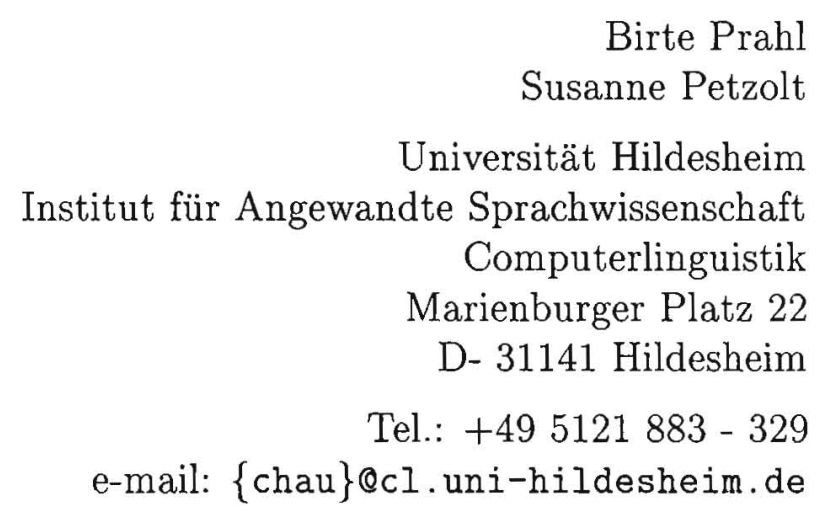

Gehört zu den Antragsabschnitten: 13.2 Übersetzungsstrategien I und 13.8 Kontrolle und Bewertung

Die vorliegende Arbeit wurde im Rahmen des Verbundvorhabens Verbmobil vom Bundesministerium für Bildung, Wissenschaft, Forschung und Technologie (BMBF) unter dem Förderkennzeichen 01 IV 101 P 5 gefördert. Die Verantwortung für den Inhalt dieser Arbeit liegt bei den Autorinnen. 
Translation problems and translation strategies: Empirical studies

\section{Contents}

1 Introduction

1.1 Study I: Translation of an ambiguous text with no contextual information . . . . . . . . . . . . . . 6

1.2 Study II: Translation of a Verbmobil dialogue . . . . . . . . . . . 10

2 Consequences for Machine Translation $\quad 16$

3 References $\quad 20$ 


\section{Introduction}

The aim of our article is to demonstrate that an investigation of human translation strategies can help to develop working hypotheses for machine translation. We would also like to take the opportunity to illustrate how fruitful interdisciplinary research work can prove to be.

The investigation of human translation ${ }^{1}$ strategies is relevant to research carried out in various fields. Researchers working in the field of translation science, didactics, psycholinguistics, second language acquisition and cognitive sciences are all interested in learning more about how humans transfer information from one natural language to another and which strategies they employ in order to cope with possible difficulties (see also [Moser-Mercer97]). Obviously, issues related to the field of machine translation are closely connected with questions regarding human translation strategies, e.g. how to cope with information deficits. Astonishingly, researchers from both disciplines have in the past shown relatively little interest in each other's results. Both could, however, profit from an exchange:

On the one hand, insights into human translation processes could lead to improvements in a system's translation performance as well as to more appropriate man-machine interaction when the machine is used as a tool for professional translators.

On the other hand, when investigating human translation processes with a view to using the results for machine translation, we are forced to concentrate on dealing with certain phenomena such as the resolution of structural or referential ambiguities. Machine translation requires well-defined formalisms; hypotheses within translation science must be described precisely, thus encouraging progress in this field of research.

The German research project Verbmobil is the first step towards investigating both human and machine translation strategies. Our Verbmobil subgroup concentrates on the study of human translating and interpreting strategies and their relevance for formalized models of the translation process.

We carry out our work in two stages: Firstly, we analyse the data obtained from real bilingual appointment scheduling dialogues with respect to the linguistic phenomena inherent in human interpreting strategies. From this analysis, which must obviously deal with phenomena which are of interest for machine translation, we then produce working hypotheses for machine translation. These must be discussed in the context of the project and can be regarded as a basis for formal models of the translation process.

As a result, we obtain hypotheses which have proved to be of importance for the subject of our interest, i.e. the investigation of human strategies with respect to

\footnotetext{
${ }^{1}$ The concept of "translation" applies to both written and spoken language. When referring to the written form only, we will explicitly speak of written translation.
} 
machine translation.

In the following we shall describe our theoretical background (section 2) as well as two explorative studies (section 3). The aim of the studies presented in this paper is to give special attention to the investigation of human standard assumptions with regard to the use of defaults in machine translation ${ }^{2}$. In section 4 we shall explain how the use of defaults is connected with questions concerning the relevance of information in translation and describe some consequences of our investigations for machine translation, e.g. we shall show how to implement the results of our studies in the Verbmobil machine translation system.

In order to evaluate the results, we must bear in mind that studies concerning the human translation process itself do not have a long tradition in translation science (cf. [Krings86]; [Moser-Mercer97]). Translation science has in the past mainly been concerned with the product of the translation process. The interpreting of dialogue, upon which this project is based, is especially unexplored. Up to now, research interest has focused on the investigation of simultaneous interpreting.

We can thus say that the focus of our interest gives rise to new questions and calls for new methods of investigation.

\section{Theoretical background}

Researchers working in the field of translation science have recently shown an interest in the process-oriented view of translation [Krings86], [Lörscher91]. In this context of process-oriented research, we are interested in the strategies used by human interpreters to cope with translation problems.

First we must define the concepts of translation strategy and translation problem. We refer here to a concept used in research into second language acquisition. The definition of "translation strategies" can be constructed in analogy to a concept from communication science: Translation strategies are "potentially conscious plans to solve what, to an individual, presents itself as a problem in reaching a particular translation goal" (adapted from [Krings86]). Additionally, it was important at the start of our investigations to define the concept of "translation problem". Until now, translation theory and machine translation have defined translation problems in the following way:

Translation theory makes a distinction between Übersetzungsprobleme 'translation problems' and Übersetzungsschwierigkeiten 'translation difficulties' [Nord91]. In [Nord91], the linguistic phenomena known to be problematic in translation independent of the individual translator, e.g. ambiguous verbs, prepositions etc., are Übersetzungsprobleme. In contrast, Übersetzungsschwierigkeiten refers to the cases in which the individual translator could have difficulties in coping with pro-

\footnotetext{
${ }^{2}$ We use the term "standard assumption" in connection with human translation behaviour and "default" with regard to machine use only.
} 
blematic linguistic phenomena or other problematic conditions in the translation process. [Krings86], in his studies of the human translation process, uses several "indicators" as criteria for the existence of a translation problem, for instance corrections made to the target language text.

Machine translation, on the other hand, refers to translation problems as translation mismatches. The notion of "translation mismatch" refers to cases in which a source language expression is confronted by several target language equivalents. This definition ignores the quite normal "unsymmetrical" equivalence between source language expressions and target language expressions, which depends on the language pair involved. In translation sciences it is well known that "translation mismatches" are normal and are not a problematic case (see also [des Tombe92];[des Tombe97] and [Pause97] on symmetrical relations in translation). Both definitions are not suitable for our approach as we require a definition which describes human translation behaviour and can also be applied to machine translation. Machine translation thus requires a definition which makes explicit what is to be regarded as a problem and what is not.

Subsequently, we distinguish between potential and actual translation problems. We say that a potential translation problem becomes an actual translation problem when there is an information deficit at a certain point in time-without taking into account whether the translator is aware of this information deficit or not. An actual translation problem is based on the existence of an information deficit as an explicit criterion.

In the context of our work we would like to concentrate on actual translation problems and the question as to which strategies human translators use in order to cope with information deficits (either consciously or unconsciously).

Since there is no definition which is useful for our purpose-neither in translation theory nor in machine translation-of the concept of "translation problem", we have developed the following criteria which allow us to define an actual translation problem:

An actual translation problem is characterized by the presence of the following four factors:

1. A decision must be made during the translation process,

2. but there is an information deficit

3. at a specific moment within the translation process

4. in a certain context. 
It is widely accepted that the process of translation can be regarded as a decisionmaking process [Levý81]. When a decision relevant to the translation process cannot be made due to an information deficit, the translator is confronted with a translation problem.

As only a limited amount of knowledge is available to the human translator as well as to the machine translation system, the relevance of the missing information is of importance. We shall elaborate on this topic in section 4 .

Another important concept we use in our work is the translation target. This determines what is important in a particular translation. In short, the overall translation target can be derived from the translation order, which specifies all circumstances relevant to the translation, e.g. the receiver of the translation, the text type and the function of the translated text. The translation target therefore specifies which of the implicit and explicit information contained in the source language expression is of importance and should be transferred to the target language. Thus, relevance of information (or of missing information) is the basis for deciding which strategy is most adequate. (see also [Nord91]; [Albrecht90]; [Holz-Mänttäri90]; [Neubert90]; [Neunzig-Presas94]; [Vermeer86]; etc. and [Schmitz97], who uses the term "translation objective" for what we call "translation target".)

In a first attempt at a definition, we distinguish the following types of human translation strategies (see [Hauenschild-Prahl93]; [Prahl94a]):

- Reduction strategies:

The missing information is not relevant at a given point in time, and the translator can for example use a generalization.

- Achievement strategies:

The missing information is relevant at a given point in time, and the translator tries to obtain more information.

Both types of strategies are influenced by standard assumptions in a complex way which cannot be described in the context of this paper. However, human translators use different kinds of standard assumptions ([Jackendoff83]; [Icking95] which could be used as models in the implementation of defaults for machine use. In the following we shall describe two studies of the translation process which deal with missing information. According to our definition of a translation problem based on an "information deficit", we have confronted translators with translation problems. We shall illustrate the use of human standard assumptions using examples taken from the two studies. 


\section{Studies}

The studies described in the following focus on the use of human standard assumptions. We shall present selected examples only (for a complete description, see [Prahl94b] and [Petzolt-Prahl95].

\subsection{Study I: Translation of an ambiguous text with no contextual information}

\section{Method:}

In this study, the subjects were asked to translate the following text from German into English. ${ }^{3}$ The text is grammatically correct but cannot be understood outside a certain situational context, which can be provided-or, in this case, withheld-in the form of a picture (see figure 1).

Wenn die Ballone platzen, würde man den Ton nicht hören, weil die Entfernung bis zum richtigen Stockwerk zu groß wäre. Auch ein geschlossenes Fenster würde den Ton hindern, da die meisten Gebäude gut isoliert sind. Da das ganze Unternehmen darauf beruht, daß der elektrische Strom nicht unterbrochen wird, würde es auch zu Problemen kommen, wenn der Draht in der Mitte abreißen würde. Natürlich könnte der Kerl auch schreien, aber die menschliche Stimme ist nicht laut genug, um so weit zu tragen. Ein zusätzliches Problem ist, daß am Instrument etwas brechen könnte, dann gäbe es zur Botschaft selbst keine Begleitung. Es ist klar, daß bei geringerer Entfernung die Probleme kleiner wären. Bei einem face-to-face-Kontakt wäre die Wahrscheinlichkeit am kleinsten, daß etwas schiefginge. [Hörmann 81]

The examples we shall focus upon are given in italics. We were interested in the following question: Can this text be translated without contextual information, which would be necessary for interpreting ambiguities within the text?

All ambiguous terms must be regarded as actual translation problems because of the information deficit and, as we shall demonstrate below, the translators used various strategies in order to cope with these difficulties.

We used two groups of subjects: (a) 12 students studying technical translation at Hildesheim University and (b) 3 native speakers of English who teach English and translation at the same university. In addition, we recorded the comments which the subjects made on completion of their translations.

\footnotetext{
${ }^{3}$ The original English version of the text is by [Bransford-Johnson73], see appendix. The German translation is by [Hörmann81].
} 


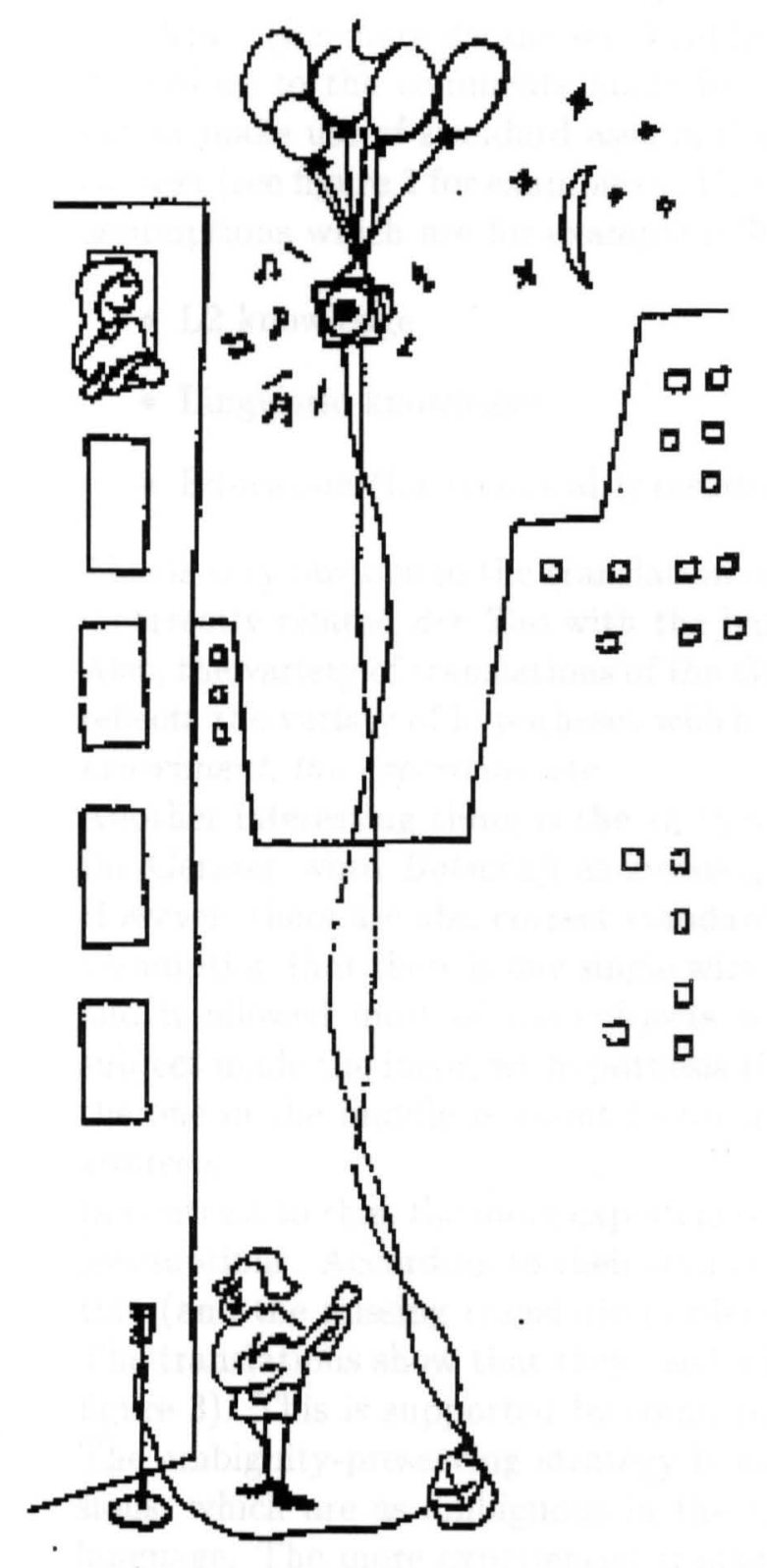

Figure 1: Contextual information for study I 


\section{Results:}

The translations of the two groups of subjects show remarkable differences when compared. Learners on the one hand and more professional translators on the other use different types of strategies when confronted with the same translation problems $^{4}$ (for more details see [Prahl94b]).

According to the comments made by the students themselves, they to a great extent make use of standard assumptions which they derive from a hypothetical context (see figure 2 for examples). This hypothetical context is based on different assumptions which are for example influenced by the following factors:

- L2 knowledge

- Linguistic knowledge

- Education (for technical translators)

This is very obvious in the translation of the German der Ton: The students who incorrectly related der Ton with the balloons translated it as noise or bang. Also, the variety of translations of the German expression das ganze Unternehmen reflects the variety of hypotheses which the students used: the whole problem, the experiment, the experience etc.

Another interesting thing is the-in this context-completely wrong translation of the German word Botschaft as embassy.

However, there are also correct standard assumptions: for example, the standard assumption that there is one single wire which is to break in the middle is correct, and it allowed most of the subjects to translate the text correctly. Only one subject made the incorrect hypothesis that there are at least three wires, of which the one in the middle is about to break. We call this strategy a disambiguating strategy.

In contrast to this, the more experienced translators tried to avoid using standard assumptions. According to their own comments, the missing contextual information (and the missing translation order) caused them to avoid interpretation.

The translations show that they used a kind of ambiguity-preserving strategy (see figure 3). This is supported by comments made by the translators themselves.

The ambiguity-preserving strategy is marked by the use of more general expressions, which are as ambiguous in the target language as they are in the source language. The more experienced translators translated

- der Ton as the sound and

- das ganze Unternehmen as the whole thing or the whole enterprise

\footnotetext{
${ }^{4}$ The translations of the whole text by two students and one native speaker are given in the appendix.
} 


\begin{tabular}{|c|c|}
\hline der Ton & $\begin{array}{l}\text { noise }(4 \mathrm{x}) \\
\text { sound }(4 \mathrm{x}) \\
\text { signal }(1 \mathrm{x}) \\
\text { hear it }(1 \mathrm{x}) \\
\text { bang }(1 \mathrm{x}) \\
\text { tone }(1 \mathrm{x})\end{array}$ \\
\hline $\begin{array}{l}\text { das ganze } \\
\text { Unternehmen }\end{array}$ & $\begin{array}{l}\text { business }(3 \mathrm{x}) \\
\text { process }(2 \mathrm{x}) \\
\text { problem }(2 \mathrm{x}) \\
\text { experiment }(1 \mathrm{x}) \\
\text { experience }(1 \mathrm{x}) \\
\text { enterprise }(1 \mathrm{x}) \\
\text { fail }(2 x)\end{array}$ \\
\hline der Draht in der Mitte & $\begin{array}{l}\text { the wire in the middle/ } \\
\text { in its middle }(10 \mathrm{x}) \\
\text { a wire in the middle }(1 \mathrm{x}) \\
\text { fail }(1 x)\end{array}$ \\
\hline Instrument & $\begin{array}{l}\text { instrument }(10 \mathrm{x}) \\
\text { technical device }(1 \mathrm{x}) \\
\text { fail }(1 x)\end{array}$ \\
\hline Botschaft & $\begin{array}{l}\text { message }(10 \mathrm{x}) \\
\text { embassy }(2 \mathrm{x})\end{array}$ \\
\hline
\end{tabular}

Figure 2: Study I: Translations produced by translation students 


\begin{tabular}{|ll|}
\hline der Ton & sound $(3 \mathrm{x})$ \\
\hline $\begin{array}{l}\text { das ganze } \\
\text { Unternehmen }\end{array}$ & $\begin{array}{l}\text { the whole enterprise } \\
\text { the whole thing } \\
\text { the whole undertaking }\end{array}$ \\
\hline der Draht in der Mitte & to break in the middle $(3 \mathrm{x})$ \\
\hline Instrument & instrument $(2 \mathrm{x})$ \\
& equipment \\
\hline Botschaft & message $(2 \mathrm{x})$ \\
& error message \\
\hline
\end{tabular}

Figure 3: Study I: Translations produced by English teachers

These English translations are more general expressions than those produced by the students.

To sum up, the aim of the study was to become acquainted with the types of strategies and standard assumptions which translators use when they cannot fully understand a text. As we were able to demonstrate, virtually only learners (the students) use (lexical) standard assumptions based on misleading hypotheses and leading to partially incorrect translations. More experienced translators avoid the use of (lexical) standard assumptions and instead try to preserve the degree of ambiguity present in the original.

As a first conclusion, we can say that standard assumptions cannot be used correctly when essential information about the context is not given.

\subsection{Study II: Translation of a Verbmobil dialogue}

The aim of the second study is to investigate the use of standard assumptions in a more stereotyped environment, allowing a great deal of contextual informations to be inferred from the situation itself (or the co-text). For a detailed description of the study and its results see [Petzolt-Prahl94].

\section{Method:}

The material we used for the second study was an artificially constructed German/English appointment scheduling dialogue containing various kinds of poten- 
tial translation problems.

In the context of this paper we would like to focus on examples revealing the following problems, which we then intend to investigate with regard to the use of standard assumptions: ${ }^{5}$

1. idiomatic expressions

2. ambiguous verbs and

3. time references

The subjects (S) were 8 semi-professional translators completing their translation studies at Hildesheim University.

The subjects were asked to translate the utterances of both speakers into the other language and write down their translations. While doing this they were asked to think aloud, which means verbalizing whatever goes through their minds.

This so-called "thinking-aloud method" has been well-known in psychology since the beginning of the century. It is relatively new in translation science, the traditional focus of this field of research being on the product of the translation process. The increasing interest in the mental activities concerned put the process of translation itself into the centre of interest ([Krings86]; [Lörscher91]) (for models of the translation process see also [Moser-Mercer97]). It was Krings [Krings86] who made the thinking-aloud protocols (TAP) popular as a "suitable online method for investigating the translation process". This is supported by the argument that translation is a linguistic problem-solving task and that translating and thinking aloud are related processes [Krings86: 92].

Critics often point out that the TAP method involves the following problems:

- It is probable that most of the cognitive processes involved are unconscious and thus cannot be verbalized by the subjects [Schmidt94].

- Interferences between verbalization and the cognitive effort involved in translating affect the translation process.

- The subjectivity of the TAP method is partly due to the different ways in which different translators apply it.

We shall have to keep these problems in mind when exploiting the results of such studies.

\footnotetext{
${ }^{5}$ For the complete dialogue see the Appendix.
} 
The disadvantage of investigating the process of interpreting (in contrast to studying written translation) with thinking-aloud-methods is that it can only be done retrospectively. For this reason, we have designed a study dealing with written translating, and we hope to be able to apply some of the results gained here to the process of interpreting. The advantage of investigating the process of written translation is that the period between the work of translating and the verbalization of thought is very short.

The important thing about this study is that we presented the dialogue without giving any further information about the occasion on which it took place and the characters involved in it. It was presented piece by piece (or turn by turn) so that the translators could not obtain a general view of the dialogue. Our hypothesis was that translators need to use standard assumptions of some description in order to interpret ambiguous expressions.

\section{Results:}

\section{Idiomatic expressions:}

In sentence 7: Ja, Moment, ich muß erst mal einen Blick in meinen Terminkalender werfen, the idiomatic expression $J a$, Moment is of interest.

For the German expression $J a$, Moment, all subjects chose idiomatic expressions. Subject 3 gave two alternative translations for the deliberation: 'one moment, please' and 'hold on, please'. She claimed that she didn't know whether it was a phone call or a face-to-face dialogue: "It is possible that it is a telephone call; then the translation would be: 'Hold on, please.'." One might conclude that all of the other subjects used the standard assumption that it was a face-to-face dialogue.

\section{Ambiguous verbs:}

The object of the verb to see in sentence 4 (see figure 4) is software. The speaker does not specify exactly what he wishes to do with the software. This gives room for various interpretations. In our opinion, these interpretations are based on standard assumptions corresponding to knowledge of the world:

Thus, for example, subjects 3 and 6 thought that a literal translation (to see as sehen) would be misleading. They therefore interpreted to see as kennenlernen 'to get to know'.

Subject 7 understood to see as ausprobieren 'to try out', erfahren 'to learn'. Her translation was etwas über Ihre Software erfahren 'to learn something about your software'. Subjects 2 and 4 translated to see your software as bin an Ihrer Software interessiert 'I am interested in your software'. Only subjects 1 and 8 translated literally as sehen 'to see'. 
We can see that a lot of subjects use the standard assumption that to see software means a lot more than to look at the floppy disk containing the software.

\section{Temporal references:}

Some of the temporal references contained in the dialogue are not explicit and cannot be disambiguated without contextual information. For example, expressions of time in hours are, in German as well as English, often given without reference to the time of day to which the speaker is referring, as in let's meet at nine.

However, in our special dialogue situation, we can assume that business partners meet during the daytime (especially for a software demonstration). It might be possible to translate the time references so that they are as ambiguous in the translation as they are in the source text, but if an appointment is scheduled in the dialogue, expressions of time should be translated as precisely as possible. In sentence 9 , only subjects 3,4 and 7 disambiguate half past one by giving the German daytime reference ${ }^{6}$ and subject 7 comments on this with: "With the expression 'half past two' she probably refers to daytime" (see figure 5).

The comments made by subject 7 are particularly interesting:

Sentence 9: Sie meint wohl tagsüber mit halb zwei, also 13:30.

'With the expression 'half past two' she probably refers to daytime.'

Sentence 10: "Da" bezieht sich wohl auf den Tag und die Uhrzeit.

"there" probably refers to the day and time.'

To sum up: in the second study, the subjects were able to infer a lot of information from the given situation by means of standard assumptions.

We would once more like to stress that the two studies were carried out for different purposes:

In the first study, our intention was to illustrate the extent to which standard assumptions are employed without any context at all. The experts used a convincing strategy to cope with ambiguities: translating while preserving ambiguity.

The second study allowed us to demonstrate that there was an increased probability of the standard assumptions being correct. We were able to show that translators are capable of using standard assumptions the more sensibly the more stereotyped the situational context is. In our view, this has certain consequences for machine translation.

\footnotetext{
${ }^{6}$ The translation by subject 4 as " $12: 30$ " could be a mistake.
} 
4. Yes, my name is Beth Shields from Beth Industries and I would very much like to see your software.

S 1: Ja, mein Name ist Beth Shields von der Firma Beth Industries, und ich würde sehr gerne Ihre Software sehen.

S 2: Ja, ich bin Beth Shields von Beth Industries, und ich bin sehr an Ihrer Software interessiert.

S 3: Ja, ich heisse Beth Shields von Beth Industries und ich würde mich sehr freuen Ihre Software kennenzulernen.

Comment:To see-hier nicht sehen, sondern kennenlernen logischerweise.

'In this case it doesn't mean 'to see' but 'to get to know', of course.'

S 4: Ja, das ist richtig. Mein Name ist Beth Shields. Ich komme von Beth Industries, und ich bin an Ihrer Software interessiert.

S 5: Ja, richtig, mein Name ist Beth Shields von Beth Industries. Ich wäre sehr daran interessiert, mich über Ihre Software zu informieren.

S 6: Ja, mein Name ist Beth Shields von Beth Industries, und ich würde mich sehr darüber freuen, Ihre Software kennenzulernen.

Comment:Kennt sie die Software schon vorher? Wahrscheinlich nicht, deshalb nehme ich dann kennenlernen. 'Is she already familiar with the software? Probably not, so I'll choose 'to get to know'.'

S 7: Ja, das stimmt, mein Name ist Beth Shields von Beth Industries und ich würde mich sehr freuen etwas über Ihre Software zu erfahren.

Comment: Will nicht nur sehen, sondern auch ausprobieren, etwas erfahren. 'Does not only want to see, to look at, but also to try out, to experience.'

S 8: Ja, mein Name ist Beth Shields von der Firma Beth Industries und ich würde sehr gerne Ihre Software sehen.

Figure 4: Study II: Written translations and comments (sentence 4) 
9. Oh, let's see. yes, I'm free until half past one on Wednesday the third (Pause) november.

S 1: Hmm, mal seh'n. Ja, ich habe Zeit bis halb zwei am Mittwoch, den dritten - November.

S 2: Hmm, lassen Sie mich mal schauen... Ja, am Mittwoch, dem dritten November bin ich bis halb zwei frei.

S 3: Oh, einen Augenblick bitte. Ja, doch, am Mittwoch, den 3. November kann ich Ihnen bis $\mathbf{1 3 . 3 0}$ zur Verfügung stehen.

S 4: Warten Sie einen Moment. Ja, mir paßt der dritte November. Ich hätte bis um 12:30 Uhr Zeit.

S 5: Mal seh'n. Am Mittwoch (Pause), den dritten habe ich bis halb zwei Zeit.

S 6: Oh, mal schauen. Ja, am Mittwoch, dem 3. (Pause) November, bin ich bis halb zwei frei.

S 7: Oh, mal sehen. Ja, am Mittwoch, dem 3. November habe ich bis 13.30 Zeit.

Comment:Sie meint wohl tagsüber mit halb zwei, also 13:30. 'With the expression 'half past two' she probably refers to daytime.'

S 8: Lassen Sie mich mal nachsehen. Ja, am Mittwoch, dem 3. November habe ich bis halb zwei Zeit.

Figure 5: Study II: Written translations and comments (sentence 9) 


\section{Consequences for Machine Translation}

In the following we would like to describe certain working hypotheses for a machine translation system which we have derived from the studies described above. We shall then present some preliminary conclusions on the use of defaults in a machine translation system. The main points of interest with respect to human standard assumptions in our studies are as follows:

- The first study aimed to investigate how human translators translate a text which is not fully comprehensible. The conditions of the first study can thus be considered as analogous to those of a machine translation system, which cannot understand what a text is about. Under these conditions human translators translated the text in two different ways: Those who were able to identify potential ambiguities translated the text into the target language with ambiguities. They realised that they could not make inferences due to their lack of information. On the other hand, some of the students used wrong standard assumptions to disambiguate the text. They interpreted ambiguous expressions incorrectly (e.g. German Instrument-which in this case was a musical instrument-as technical device).

Thus, it seems that only the experts used a sensible translation strategy, which could be defined as follows: "When translating without contextual knowledge and translation order, try to preserve the degree of ambiguity and avoid the use of standard assumptions."

However, ambiguity is only one of the possible translation problems experienced by a human or a machine when confronted by lack of information. It is possible to formulate several different problems and possible problem-solving strategies, and these strategies are carefully weighed up by the translator.

- In the second study, the subjects were confronted by the Verbmobil situation: translating a Verbmobil scenario text (a professional appointment scheduling dialogue) without further information.

Due to their knowledge of the scenario, human translators confronted by a situation analogous to that typical for the Verbmobil system were able to use many standard assumptions (on the structure of appointment scheduling dialogues see [Jekat97], on the importance and the use of discourse information for machine interpretation see [Luper-Foy97]). Thus, they were able to translate the text correctly although the situational specifications were missing.

We hope that these examples illustrate the relevance of standard assumptions in the human translation process. 
Trying to apply the concept of standard assumptions to machine translation, the following can be said: In analogy to standard assumptions in human translation, machine translation systems use so-called defaults for the formalization of uncertain knowledge (described in [Schmitz-Quantz93]). According to our investigation of the use of standard assumptions in the human translation process, we can conclude that the following criteria are of importance for the use of defaults where knowledge is uncertain or information is missing (on incomplete information in Verbmobil see also [Jekat97]): The relevance of the missing information, the amount of effort necessary to obtain further information, and the probability that the assumed default is correct.

\section{Relevance of the missing information}

As we pointed out above, relevance must be inferred from the so-called translation order. The translation order tells us which implicit and explicit information of a source language expression can be of importance in a specific situation (scenario). It thus lets us know which information must be transferred to the target language. Relevance of information, which is derived from the translation order (see also Nord's "function of a text" [Nord97]), is the main factor in deciding what to translate and how to translate it. It is thus possible for us to determine the relevance of missing information: When we know which information is relevant in a scenario, we can make an estimation of the relevance of missing information (on relevance in translation see also [Schmitz97]).

For application in machine translation, "relevance" can be defined by the so-called "translation targets" for a given scenario [Prahl et al.95]. Translation targets can be regarded as a formalization of relevance for machine use.

In the first study, the importance of the missing information could not be determined because the translation order and the contextual knowledge were missing. In the second, it was possible to infer importance from the scenario, which provides an implicit translation order and reveals what is important and what is not.

\section{Amount of effort necessary to obtain further information}

This is another important factor in deciding what could be an adequate translation strategy at a certain point in time. A certain amount of effort must be invested in order to obtain the information required. The amount must be calculated with respect to the kind of information deficit involved and the possible source of information.

As the type of information deficit is concerned, the following questions can be asked: 
Is the deficit due to

- deficitory (e.g. accoustic) input?

- deficits in basic knowledge (grammatical rules, lexical knowledge)?

- deficits in situational knowledge?

- etc.

For the possible source of information the questions are:

Can the deficit be compensated by

- further efforts to analyse the input?

- information provided by other modules of the system?

- clarifying dialogues (asking the user)?

In our first study, for example, there was no way of obtaining the information required. Due to missing contextual knowledge, it was not possible to compensate for the deficit.

\section{Probability that the default is correct}

This must be inferred from the context and is connected with the scenario. The scenario defines the probability of contextual factors. In a professional appointment scheduling dialogue, the contextual factors for instance tell us that it is highly probable that the meeting will take place during the daytime (see figure 5, subject 7).

When we consider the studies in the light of these criteria, we can say the following:

In the first study, the experts correctly decided to use as few lexical standard assumptions as possible, as they could not evaluate the relevance of the missing information due to their lack of understanding of the text (or due to missing contextual information). They thus decided to translate while preserving the degree of ambiguity. Some students used lexical standard assumptions, which sometimes resulted in an incorrect translation.

In the second study, the situation was different: The human translators were able to evaluate the probability that the standard assumptions were correct. Their contextual knowledge of appointment scheduling situations made them aware of the relevance of the missing information. They were able to infer the relevance of information from the situation although they were not given any further information.

\section{Conclusions}

Our investigations of human standard assumptions show the following:

- Standard assumptions are used to infer the missing information from the scenario, as for example in sentence 4 (see figure 4): 
S 6 : Ja, mein Name ist Beth Shields von Beth Industries, und ich würde mich sehr darüber freuen, Ihre Software kennenzulernen.

Comment :- Kennt sie die Software schon vorher? Wahrscheinlich nicht, deshalb nehme ich dann "kennenlernen". "Is she already familiar with the software? Probably not, so I'll choose 'to get to know'.'

- Additionally, the probability that the standard assumption is correct must be high, in order to minimize the risk involved in translating on the basis of uncertain knowledge. This is illustrated by sentence 9 :

S 7 : Oh, mal sehen. Ja, am Mittwoch, dem 3. November habe ich bis $\mathbf{1 3 . 3 0}$ Zeit.

Comment : - Sie meint wohl tagsüber mit halb zwei, also 13:30. 'With the expression 'half past one' she probably refers to daytime.'

- The amount of effort made in order to obtain further information cannot be investigated in our studies because it was not possible for the subjects to obtain more information on the context.

If we apply the criteria given above to the Verbmobil scenario, we can determine the "importance" of information and define translation targets which formalize the relevance of information for the system (see Schmitz's "translation objective" [Schmitz97], where "importance of information" is applied to MT). The following translation targets have been suggested for the "negotiation phase" of the appointment scheduling dialogue [Schmitz97]:

- Rendition of the dialogue act

- Precise description of time and place

- Intermediate level of politeness

The relevant information is thus as follows:

- Information on the interaction. It is important to transfer the dialogue act indicating the verbal actions of the dialogue partners.

- Information on all expressions with temporal and local referents.

- An intermediate level of politeness should be maintained in the output, in order to avoid analytical effort on the level of personal relations. 
We would like to stress that the scheme described above is merely one possible scheme for tackling problems involved in machine translation. In a machine interpreting system such as Verbmobil, it will be necessary to collect all information it is possible to obtain and to make use of those models which succeed in producing the best hypotheses as regards semantic evaluation. Thus, the most sensible course is probably to have different concepts of analysis from which the most suitable can be chosen for each individual case.

\section{References}

[Albrecht90] Albrecht, Jörn: "Invarianz, Äquivalenz, Adäquatheit", in: Reiner Arntz-Gisela Thome (eds.), 1990, pp.71-81.

[Arntz-Thome90] Arntz, Reiner-Gisela Thome (eds.): ÜbersetzungswissenschaftErgebnisse und Perspektiven (Festschrift für Wolfram Wilss). Tübingen: Narr, 1990.

[Bransford-Johnson73] Bransford-Johnson: "Considerations of some problems of comprehension", in: W.Chase (ed.), Visual information processing. New York, 1973.

[desTombe92] des Tombe, Louis: "Is translation symmetric?", meta XXXVII, 4: 791-801, 1992.

[desTombe97] des Tombe, Louis: "Compensation", in: [Hauenschild-Heizmann97], pp. 157-174.

[Hauenschild-Prahl93] Hauenschild, Christa-Birte Prahl: Translationsprobleme-Translationsstrategien. Verbmobil-Memo 4, Universität Hildesheim, November 1993.

[Holz-Mänttäri90] Holz-Mänttäri, Justa: "Das Transfer Prinzip", in: Reiner Arntz-Gisela Thome (eds.), 1990, pp. 59-70.

[Hörmann81] Hörmann, Hans: Einführung in die Psycholinguistik. Darmstadt: Wissenschaftliche Buchgesellschaft, 1981.

[Icking95] Icking, Barbara: Die Rekonstruktion von Desambiguierungsstrategien im Ubersetzungsprozeß. Diplomarbeit, Institut für angewandte Sprachwissenschaft, Universität Hildesheim, 1995.

[Jackendoff83] Jackendoff, R.: Semantics and Cognition. Cambridge: MIT Press, 1983.

[Jekat97] Jekat, Susanne: "Automatic interpreting of dialogue acts", in: [Hauenschild-Heizmann97], pp. 145-156.

[Krings86] Krings, Hans P.: Was in den Köpfen von Übersetzern vorgeht. Eine empirische Untersuchung zur Struktur des Übersetzungsprozesses an fortgeschrittenen Französischlernern. Tübingen: Narr, 1986.

[Levý81] Levý, Jiři: "Übersetzung als Entscheidungsprozeß”, in: Wolfram Wilss (ed.), Übersetzungswissenschaft. Darmstadt: Wissenschaftliche Buchgesellschaft, 
pp. 219-235, 1981.

[Lörscher91] Lörscher, Wolfgang: Translation performance, translation process, and translation strategies: a psycholinguistic investigation. Tübingen: Narr, 1991.

[Luper-Foy97] Luper-Foy, Susann: "Discourse processing for voice-to-voice machine translation", in: [Hauenschild-Heizmann97], pp. 223-250.

[Moser-Mercer97] Moser-Mercer, Barbara: "Process models in simultaneous interpretation", in: [Hauenschild-Heizmann97], pp. 3-18.

[Neubert90] Neubert, Albrecht: "Übersetzen als Aufhebung des Ausgangstextes", in: Reiner Arntz-Gisela Thome (eds.), 31-39, 1990.

[Neunzig-Presas94] Neunzig, Wilhelm-Marisa Presas: "Der Übersetzer in der Zwickmühle. Überlegungen zur Rolle des Übersetzers in der zweisprachigen Kommunikation", TcT 9: 79-94, 1994.

[Nord91] Nord, Christiane: Textanalyse und Übersetzen. Heidelberg: Groos, 1991.

[Nord97] Nord, Christiane: "The importance of functional markers in (human) translation", in: [Hauenschild-Heizmann97], pp. 35-50.

[Pause97] Pause, Peter E.: "Interlingual strategies in translation", in: [Hauenschild-Heizmann97], pp. 175-192.

[Petzolt-Prahl95] Petzolt, Susanne-Birte Prahl: Standardannahmen von Humantranslatoren im VERBMOBIL-Szenario-eine explorative Studie des Übersetzungsprozesses. Verbmobil-Memo 58, Universität Hildesheim, January 1995.

[Prahl94a] Prahl, Birte: Typen von Reduktion im Translationsprozess. Verbmobil-Memo 34, Universität Hildesheim, August 1994.

[Prahl94b] Prahl, Birte: Menschliche Desambiguierungsstrategien für die Maschinelle Übersetzung? Ein Beispiel für ambiguitätserhaltende Übersetzungen. Verbmobil-Memo 54, Universität Hildesheim, Dezember 1994.

[Prahl et al.95] Prahl, B.-S. Petzolt-S. Heizmann-C. Hauenschild: Variable Analysetiefe und Bewertungskriterien in VERBMOBIL: Translationswissenschaftliche Grundlagen. Verbmobil-Report 54, February 1995.

[Schmidt94] Schmidt, Annemarie: "Gruppenprotokolle - ein Einblick in die black box des Übersetzens?" Textcontext 9: 121-146, 1994.

[Schmitz97] Schmitz, Birte: "The translation objective in automatic dialogue interpreting", in: [Hauenschild-Heizmann97], pp. 193-210.

[Schmitz-Quantz93] Schmitz, Birte-Joachim Quantz: Defaults in Machine Translation, KIT-Report Nr. 106, Technische Universität Berlin, 1993.

[Vermeer86] Vermeer, H.J.: "Übersetzen als kultureller Transfer", in: Mary Snell-Hornby (ed.) Übersetzungswissenschaft: Eine Neuorientierung. Francke Verlag, 1986. 


\section{Appendix}

\section{Study $\mathbf{I}^{7}$}

\section{The English original text:}

If the balloons popped the sound wouldn't be able to carry since everything would be too far away from the correct floor. A closed window would also prevent the sound from carrying, since most buildings tend to be well insulated. Since the whole operation depends on a steady flow of electricity, a break in the middle of the wire would also cause problems. Of course, the fellow could shout, but the human voice is not loud enough to carry that far. An additional problem is that a string could break on the instrument. Then there could be no accompaniment to the message. It is clear that the best situation would involve less distance. Then there would be fewer potential problems. With face-to-face contact, the least number of things could go wrong. (Bransford-Johnson 1973)

Since it was a German/English study, we used the German translation by (Hörmann 1981) as a basis. This text can be found in section 3.1.

\section{"Ambiguity preserving translation" of a native speaker:}

If the balloons burst, one would not hear the sound, as it would be too far away from the right floor. A closed window would also deaden the sound, as most buildings are, of course, well insulated. Since the whole undertaking depends on the fact that the electric current is not interrupted, problems would arise if the wire were to break in the middle. Of course, the fellow could also shout, but the human voice is not loud enough to carry so far. An additional problem is the fact that something might break on the instrument; in that case, the message would have no accompaniment. It is obvious that the problems would be reduced if the distance were not so great. In face-to-face contact, things would be least likely to go wrong.

\section{Two "disambiguating translations" by students:}

If the ballons were bursting you wouldn't hear the bang due to the fact that the distance to the corresponding floor would be too great. Also a closed window would represent an impediment for the tone because most of the buildings are decently isolated. This whole business depends on the closed electrical circuit. Therefore problems would turn up if the electrical medium is destroyed. Obviously this bloke could screaming blue murder but the human voice would not be sufficient to convey the message about this distance. In addition another problem represents the possibility that some parts of this technical devise could suffer a technical breakdown. Consequently only the message could be received. Concerning a face-to-face contact the probability that something gets on the wrong track could be near also.

When the balons pop you wouldn't hear the sound because the distance to the floor where you were able to hear the sound would be to great. Also a closed

\footnotetext{
${ }^{7}$ Please note that all spelling mistakes have been reproduced unchanged here.
} 
window wouldn't let in the sound because most buildings are isolated very well. Because the whole business based on a closed electrical circuit a problem would be a torn up wire in the middle. Of course the guy could scream but the human voice isn't loud enough to be heard for such a long distance. Another problem is that something could break on the instrument. In that case there wouldn't exist accompany to the embassy? It's obviously that problems were smaller if distances were smaller. The opertunity for having trouble would be the smallest with a face to face contact.

\section{Study II}

\section{The dialogue to be translated:}

1. A: Ja, mein Name ist Bulla von der Frank Organisation.

2. A: Meine Sekretärin hat mir Ihren Anruf ausgerichtet.

3. A: Ich habe gehört, Sie möchten sich bei uns Software zeigen lassen?

4. B: Yes, my name is Beth Shields from Beth Industries and I would very much like to see your software.

5. A: Dann würde ich doch vorschlagen, daß wir uns äh so einen Termin suchen, wo wir uns vielleicht für zwei oder drei Stunden äh treffen könnten (Pause) in den nächsten Wochen.

6. B: Ummm, is there any specific day or time that would be suitable?

7. A: Ja, Moment, ich muß erst mal einen Blick in meinen Terminkalender werfen.

8. A : Ähm, ich würde vorschlagen, also möglich wär's bei mir, daß man den Mittwoch (Pause) den dritten November nimmt. Da hätt ich Zeit äh vormittags Zeit. Gut, machen wir's am Mittwoch, da ginge das.

9. B: Oh, let's see. Yes, I'm free until half past one on Wednesday the third (Pause) november. 10. A: Ja, mir paßt das auch sehr gut. Normalerweise bringe ich da immer meine Schwiegermutter zur Massage. Sie müssen wissen, sie ist letztes Jahr schwer gestürzt und hat sich das Bein gebrochen (Pause) - ausgerechnet am Heiligen Abend - da waren wir nicht da. Und jetzt hat sie immer noch Probleme mit dem linken Ohr. Aber im Moment ist sie zur Kur.

11. B: Oh, I'm sorry.

12. A: Dann sehen wir uns dann am äh Mittwoch. Ich würd vorschlagen um zehn.

13. B: Okay, I'm looking forward to it. 